Special Focus: International Mobility and Multinational Trends

been possible only because the legal milieu does not prohibit or regulate it.

To promote quality education, it would be worthwhile to create genuine institutional links that are based on equal participation and have adequate controls related to quality and financial arrangements. As a step in this direction, the Association of Indian Universities (AIU), in 1999, formulated guidelines covering the grant of equivalence to degrees offered in India by foreign universities. The main conditions laid down are, first, that the Indian institution (partner) has adequate infrastructure and facilities as substantiated by the report of a Review Committee of the AIU; second, that the program is implemented jointly by the foreign and the Indian universities, or academic institutions affiliated to them, with both contributing to the academic program in approximately equal measure; and third, that the foreign university gives an undertaking, in the form of a certificate, that the degree or diploma awarded to the student in India would be considered as equivalent to the corresponding degree or diploma awarded by the home university, and that it would be recognized in that country as being equivalent to the corresponding degree or diploma of the awarding university.

To date, only one university has applied for the grant of equivalence. Obviously, the guidelines of the AIU are not acceptable to the foreign providers of higher education. Perhaps they feel that they can continue operation without a grant of equivalence, for there is no dearth of students wanting a foreign degree. One can understand higher education having financial aspects, but most people in India believe that it must essentially be grounded in academic values.

\title{
American Accrediting and the International Environment
}

\section{Judith S. Eaton}

Judith S. Eaton is president of the Council for Higher Education Accreditation. Address: CHEA, 1 Dupont Circle, Washington, DC 20036.

E-mail: <eaton@chea.org>

The Council for Higher Education Accreditation (CHEA) is an umbrella organization for the regional and professional accrediting agencies in the United States. A 1999 CHEA survey of participating accrediting organizations showed that 34 of the 55 CHEA regional, national, and specialized accreditors were engaged in international activity. Together, these organizations are accrediting 355 institutions or programs in 65 countries. Fifteen of these CHEA accreditors have separate standards or guidelines for reviewing institutions and programs abroad.

The findings in the CHEA survey as well as anecdotal information from various U.S. accreditors confirm that there is keen interest in expanding this quality review activity around the world. At the same time, the U.S. federal government is promoting international higher education and calling for more study abroad programs, student exchanges, and foreign-language study.

\section{Interest in U.S. Accreditation Systems}

Institutions and agencies in other countries are actively seeking more information about how U.S. accreditation works. In the last year alone, the CHEA assisted many international visitors with a particular interest in higher education accreditation and quality assurance. Other higher education associations, U.S. colleges and universities, and the U.S. federal government host hundreds of international visitors as well.

The interest of U.S. accreditors in expanded international activity and the attention that the international community is giving to U.S. accreditation standards is fueled by the expanding international mobility of students and the rapidly growing world of on-line education offered by distance-learning providers. Other factors are also involved-the need for skilled workers in an informationand service-driven international economy and the international consensus that higher education is central to the success of all economies and global well-being.

Yet, this is a difficult international, regional, and domestic environment in which to pursue the invigorated mutual interest in international quality review. When U.S. accreditors go abroad, they receive mixed reviews. Critics in some countries routinely ask whether the otherwise laudable U.S. commitment to access and participation is too flexible in its expectations concerning institutional quality. Others point to the responsibilities that accompany the dominant U.S. role in the import and export of higher education, urging the United States to do more to protect students in other countries and to improve communication and cooperation with the international community.

\section{Regional Trends}

Regionally, Europe is taking on the challenge of creating a "European higher education space" and exploring the feasibility of European accreditation of institutions and organizations. This would place a "European" stamp on 
the quality review efforts of various countries. While attractive to some leaders in European higher education, the idea of this comprehensive European stamp of quality is of concern to others. The pressure to keep the nation-state as the proper venue for quality judgments about higher education is great.

For international colleagues, understanding the U.S. system is further complicated by confusion in the use of key quality-related terms. Terms such as "accreditation" and "quality assurance" have different meanings in different countries.

In Asia, the University Mobility in Asia and the Pacific (UMAP) consortium - a group of government and nongovernment representatives of universities in the region-was formed in 1993, to meet the regional challenge of enhanced student and staff mobility. Because successful credit transfer is ultimately tied to perceptions of institutional quality, UMAP is pressured to establish additional quality assurance ties around the world.

Some of these same countries that are skeptical of greater U.S. presence internationally are experiencing domestic pressures, especially to expand access and participation in higher education within their own borders. South Africa, for example, is facing expectations to expand its higher education capacity while, at the same time, building a comprehensive quality review capacity. Such expectations demand extraordinary efforts from higher education leaders, who are expected to accomplish these goals without sacrificing quality and without additional financial resources.

Central and Eastern Europe is another region in which countries have been charged to expand student access and participation in higher education. To pursue expanded access and the attendant quality issues this raises, some countries have established accreditation councils with a variety of quality review functions. All of these councils must work hard to reconcile the expectations about quality of their traditionally prestigious institutions with the call for expanded access.

\section{U.S. Contributions}

What contributions might the U.S. accrediting community make at this time of heightened international interest in quality review? The CHEA repeatedly hears the same responses to this question. The United States could start by providing better information about its own quality review and being more explicit in its descriptions of how American accreditation operates. The United States could also provide better information about the quality of its exports-both the export of higher education offerings and of accreditation techniques. The United States could also vigorously expand efforts to promote cooperation and communication about quality assurance and accreditation throughout the world. These are some steps the United States could take to fulfill its obligations as a good colleague in the international quality review community.

\section{Providing Information}

The highly complex and extensive U.S. system is difficult to understand-even for many in the United States. Institutional accreditation is the province of both regional and national accreditors. Programmatic accreditation is the province of specialized and professional accreditors. These accreditors may or may not be recognized and sanctioned either by government or private organizations. The scope of each accreditor is distinctive, and although accreditation practices are similar in many respects, significant variations should be noted.

For international colleagues, understanding the U.S. system is further complicated by confusion in the use of key quality-related terms. Terms such as "accreditation" and "quality assurance" have different meanings in different countries. We have an obligation to improve our understanding of the use of these terms by colleagues in various countries. We would all benefit from a common language of international quality review. The CHEA provides an overview of U.S. accreditation on its website and will soon have a glossary of key accreditation and quality assurance terms available there as well.

\section{The Issue of Quality}

The United States is a major importer and exporter of higher education. While many institutions and programs operating internationally are of sound quality, there are others that have questionable practices and offer dubious claims of accredited status. One strategy for U.S. accreditors and international colleagues is to develop an approach that enables potential students and institutions to avoid these kinds of programs and institutions. The CHEA website offers "Twelve Important Questions About External Quality Review" for students looking into different programs. Although these questions were developed for U.S. students attending U.S. site-based or distance-based operations, the CHEA-working with international colleagues-could adapt this model to an international setting.

\section{International Collaboration}

U.S. accreditors need to collaborate with their international colleagues to increase mutual understanding of 
review processes and standards and to promote good practices in quality review. Organizations such as the International Network for Quality Assurance Agencies in Higher Education, the Center for Quality Assurance in International Education, and the European Network of Quality Assurance Agencies, as well as the CHEA, are attempting to meet this need through meetings, papers, and projects.

\section{Conclusion}

In the current environment, U.S. accreditors must have a strong commitment to assist the international community in obtaining information about U.S. accreditation practices, successes, and limitations. Our long history of accreditation activity should be constructively shared with colleagues in order to meet their needs. We must be good listeners and observers, respecting the diversity of traditions of higher education around the world. We must offer information and ideas in a collegial manner without attempting to influence the judgments of the international community about what is best in various and different countries. Perhaps most important of all, we must be good learners, carefully observing the successes and good practices of our international colleagues. This is an exciting time for international cooperation, and we ought to make the most of it.

\section{International Student Mobility at the Millennium: American Patterns}

\section{Hey-Kyung Koh}

Hey-Kyung Koh is program officer at the Institute of International Education, 809 United Nations Plaza, New York, NY 10017, USA.

For the first time in the 51 years since the Institute for
International Education has been collecting and publishing data on international students in its Open Doors Report on International Educational Exchange, the number of international students studying at U.S. institutions of higher education surpassed half a million. The 1999-2000 figure of 514,723 represents a 4.8 percent increase from the previous year and is based on a 92.5 percent response rate of the 2,696 colleges and universities surveyed. (The definition of an international student for the purposes of the Open Doors survey is "anyone enrolled for courses in the United States who is not an immigrant (permanent resident), or a citizen, or a refugee, or resident alien (green card holders)."

\section{Where They Come From}

International students come from all over the world, but some regions are more heavily represented in the total number of students studying in the United States. Nine of the 15 leading places of origin are located in Asia, with Asian students comprising more than half of all international students at 54 percent, Europeans, who represent 15 percent of overall international enrollments, follow the Asians. In recent years, there has been an increase in the numbers of students coming from Mexico, Brazil, and Turkey—which have risen by more than 6 percent in the past year.

\section{Where and What They Study}

Of the international students studying in this country, 48 percent are located in just 50 U.S. counties, concentrated in the larger metropolitan areas. International students in the United States study at over 2,500 institutions. While the majority of them are at a small handful of the large research universities, they are a presence at every type of institution, from specialized and professional institutions, to associate institutions, to baccalaureate, master's, doctoral, and research institutions.

Fully 20 percent of international students, or 103,215, are in the United States to study business and management, followed by engineering, which enrolls 15 percent, or 76,748 students. Of particular note are enrollments in math and computer science, which saw a dramatic increase of 18.7 percent from the previous year.

\section{PersonalProfile}

International students are mainly undergraduates, with male students outnumbering female students, although both the gender and academic level gaps have been closing in recent years. They are overwhelmingly single and are on an $F$ visa. International associate degree students numbered 59,830 , or 1.2 percent of the total associate degree enrollments in the United States; undergraduate students numbered 177,381 , or 2.7 percent of bachelor's degree enrollments; and graduate students numbered 218,219 , or 12.0 percent of total master's and doctoral degree enrollments. 